\title{
VIENNA RADIUM INSTITUTE RADIOCARBON DATES $X$
}

\section{HEINZ FELBER}

Institut für Radiumforschung und Kernphysik der Österr Akademie der Wissenschaften, Vienna, Austria

Measurements have continued with the same proportional counter system, pretreatment procedure, methane preparation and measurement, and calculation, as described previously (R, 1970, v 12, p 298-918). Uncertainties quoted are single standard deviations originating from standard, sample, background counting rates and half-life. No ${ }^{13} \mathrm{C} /{ }^{12} \mathrm{C}$ ratios were measured. mitters.

Sample descriptions have been prepared in cooperation with sub-

ACKNOWLEDGMENTS

I express my thanks to Ing L Stein for excellent work in sample preparation, and to $\mathrm{K}$ Flandorfer for careful operation of the dating equipment.

\section{SAMPLE DESCRIPTIONS}

I. GEOLOGIC, GLAZIOLOGIC, LIMNOLOGIC, AND FOREST SAMPLES

\section{A. Austria}

VRI-618. Podlanig, Kärnten

$\mathbf{2 8 , 3 0 0} \pm \mathbf{7 0 0}$

Wood in talus under Late Glacial Age ice-margin terrace, Podlanig. $\left(12^{\circ} 54^{\prime} 50^{\prime \prime} \mathrm{N}, 46^{\circ} 41^{\prime} 10^{\prime \prime} \mathrm{E}\right)$ near St Jacob im Lesachtal, Carinthia. Coll 1977 and subm by D van Husen, Geol Inst, TU Vienna. Comment $(\mathrm{DvH})$ : dates talus and stagnant water sediments of damming-up phase in Gail Valley.

VRI-619. Nieselach, Kärnten

$26,300 \pm 600$

Lignite from lignite horizon (Fritz, 1971) overlain by coarse gravel and by ground moraine at the top, Nieselach $\left(46^{\circ} 36^{\prime} 30^{\prime \prime} \mathrm{N}, 13^{\circ} 30^{\prime} 30^{\prime \prime}\right.$ E), Gail Valley, Carinthia. Coll 1977 and subm by D Van Husen. Comment $(\mathrm{DvH})$ : chronologic fixation of lignite horizon in Würm Ice age.

\section{Helfenberg series, Oö}

Samples from surroundings of Helfenberg, Mühlviertel, Upper Austria. Coll 1976 and subm by F Kral, Univ Bodenkultur, Vienna. General Comment (FK): question of forest history.

VRI-587. AfiesI

$$
750 \pm 70
$$

Wood (spruce) ca $1.5 \mathrm{~m}$ below corn-field, Afiesl $\left(48^{\circ} 35^{\prime} 15^{\prime \prime} \mathrm{N}, 14^{\circ}\right.$ $08^{\prime} 30^{\prime \prime} \mathrm{E}$ ), alt $750 \mathrm{~m}$. Comment $(\mathrm{FK})$ : date is max for end of former woodland.

VRI-588. Hinterau

$$
590 \pm 70
$$

Brown carr-peat at depth 14 to $24 \mathrm{~cm}$ above which Larix is continuously found, Hinterau ( $48^{\circ} 35^{\prime} 50^{\prime \prime} \mathrm{N}, 14^{\circ} 08^{\prime} 40^{\prime \prime} \mathrm{E}$ ), $720 \mathrm{~m}$ NN. Com- 
ment $(\mathrm{FK})$ : date indicates autochthonous Larix palynologically detected and gives max age for later clearing.

VRI-630. Flachau, Salzburg

Wood from stem below 10 ton-stone in landslide material at $-4.5 \mathrm{~m}$ in Griesgraben (47 20 $\left.20^{\prime} \mathrm{N}, 13^{\circ} 23^{\prime} \mathrm{E}\right)$, Flachau, Salzburg. Coll 1978 and subm by Forsttechnischer Dienst f: Wildbach- u Lawinenverbauung, Salzburg. Comment: dates landslide.

VRI-631. Böckstein, Salzburg

$4420 \pm 100$

Wood $13.2 \mathrm{~m}$ below ground from excavation of water power Sta Böckstein $\left(47^{\circ} 05^{\prime} 13^{\prime \prime}\right.$ N, $13^{\circ} 06^{\prime} 57^{\prime \prime}$ E) near Badgastein, Salzburg. Coll 1978 and subm by SAFE. Comment (SAFE): dates Holocene valley filling.

\section{St Martin a Tg, series, Salzburg}

Wood, St Martin am Tennengebirge, Salzburg. Coll 1978 and subm by W Weinmeister, Forsttechnischer Dienst f Wildbach- u Lawinenverbauung, Salzburg.

\section{VRI-633. Sample 1}

Branch or root ca $60 \mathrm{~cm}$ below surface in uppermost bog layer overlain by sand $\left(47^{\circ} 29^{\prime} 57^{\prime \prime} \mathrm{N}, 13^{\circ} 22^{\prime} 44.5 \mathrm{E}\right)$. Comment (WW): max age of sand deposition on alluvial cone of rivulet Schöberlbach and min age for cone.

\section{VRI-634. Sample 2}

$6130 \pm 120$

Stem at base of rivulet Schöberlbach earlier covered by $6 \mathrm{~m}$ dolomite detritus $\left(47^{\circ} 29^{\prime} 57.5^{\prime \prime} \mathrm{N}, 13^{\circ} 20^{\prime} 24^{\prime \prime} \mathrm{E}\right)$. Comment (WW): dates flood causing fall of trees into rivulet bed.

\section{VRI-464. Pass Thurn, Salzburg}

$11,560 \pm 170$

Cyperaceae peat at base $-3.2 \mathrm{~m}$ of bog Wasenmoos, Pass Thurn $\left(47^{\circ} 18^{\prime} 21^{\prime \prime} \mathrm{N}, 12^{\circ} 25^{\prime} 03^{\prime \prime} \mathrm{E}\right), 1205 \mathrm{~m}$ alt, near Mittersill, Salzburg. Coll and subm by $\mathrm{S}$ Bortenschlager, Bot Inst, Univ Innsbruck. Comment (SB): age is min of ice retreat and fixes beginning of peat growth. Expected ca 13,000 BP.

\section{VRI-594. Spital am Pyhrn, Steiermark}

$9680 \pm 210$

Wood in rubble of $\mathrm{E}$ slope of Mt Mitterberg near Spital am Pyhrn $\left(47^{\circ} 40^{\prime} \mathrm{N}, 14^{\circ} 20^{\prime} \mathrm{E}\right)$, Styria. Coll 1977 when tunneling Hwy A9 Pyhrnautobahn and subm by H Auferbauer, Steiermärkische Landesregierung, Graz. Comment (HA): dates postglacial slope overburden.

\section{Trieben series, Steiermark}

Sphagnum peat from lowland moor Aubruckermoos near Trieben $\left(47^{\circ} 29^{\prime} 20^{\prime \prime} \mathrm{N}, 14^{\circ} 30^{\prime} 30^{\prime \prime} \mathrm{E}\right)$, alt $690 \mathrm{~m}$, Styria. Coll 1974 and subm by F Kral.

General Comment (FK): dates palynologically detected events. 
VRI-500. 150-160cm

$6000 \pm 100$

Peat at depth 150 to $160 \mathrm{~cm}$. Comment (FK): date proves spreading of Abies even in more central parts of $\mathrm{E}$ Alps during middle of Atlantikum.

VRI-501. 285-300cm

$6490 \pm 90$

Peat at depth 285 to $300 \mathrm{~cm}$. Comment (FK): date proves existence of outposts of Abies spreading in older Atlantikum.

\section{Stubaital Series 1, Tirol}

Peat of bog Buntes Moor (46 $56^{\circ} 27^{\prime \prime} \mathrm{N}, 11^{\circ} 08^{\prime} 45^{\prime \prime} \mathrm{E}$ ), $2285 \mathrm{~m}$ alt, Stubai Valley, Tyrol. Coll 1973 in dug profile and subm by Sigmar Bortenschlager.

General Comment (SB): dates palynologically detected events. Completes earlier search (Mayr, 1964; 1968; R, 1970, v 12, p 303).

VRI-530. Buntes Moor 6

$\mathbf{3 1 5 0} \pm \mathbf{8 0}$

Peat at depth 279 to $285 \mathrm{~cm}$. Comment (SB): dates end of lowering timber line.

\section{VRI-531. Buntes Moor 7}

$3490 \pm 80$

Peat at depth 303 to $307 \mathrm{~cm}$. Comment (SB): dates end of growth of thickest peat layer in profile and beginning timber line decrease.

VRI-532. Buntes Moor 8

$5690 \pm 110$

Peat at depth 350 to $355 \mathrm{~cm}$. Comment (SB): dates beginning peat growth and tree pollen increase at beginning of climatic amelioration.

\section{Stubaital Series 2, Tirol}

Samples of bog near glacier Grünau-Ferner $\left(46^{\circ} 59^{\prime} 50^{\prime \prime} \mathrm{N}, 11^{\circ} 11^{\prime}\right.$ $37^{\prime \prime}$ E), $2190 \mathrm{~m}$ alt, Stubai Valley, Tyrol. Coll 1975 in dug profile and subm by Sigmar Bortenschlager.

General Comment (SB): dates palynologically detected events. Completes earlier search (Mayr, 1964; 1968; R, v 12, p 306).

VRI-533. Grïnau-Ferner 1

$6980 \pm 130$

Dy at base, depth 214 to $216 \mathrm{~cm}$. Comment (SB): dates beginning peat growth and min age for ice retreat.

VRI-534. Grïnau-Ferner 2

$6270 \pm 100$

Cyperaceae peat at depth 188 to $189 \mathrm{~cm}$. Comment (SB): dates end of peat growth and beginning of climatic deterioration.

VRI-535. Grünau-Ferner 3

$5820 \pm 100$

Cyperaceae peat at depth 134 to $144.5 \mathrm{~cm}$. Comment (SB): dates end of peat growth and beginning of climatic deterioration.

VRI-536. Grünau-Ferner 4

$4920 \pm 140$

Dy at depth 113 to $115 \mathrm{~cm}$. Comment (SB): dates end of peat growth and beginning of climatic deterioration. 
VRI-570. Ampass 1, Tirol

$25,630 \pm 660$

Earthy peat from sedimented peat band, 3 to $7 \mathrm{~cm}$ thick, in sand-siltzone ca $2 \mathrm{~m}$ thick followed by ca $20 \mathrm{~m}$ gravel overlain by 1 to $2 \mathrm{~m}$ ground moraine and recent soil. Coll 1976 near Ampass (47 $17^{\circ} 15^{\prime} 39^{\prime \prime} \mathrm{N}, 11^{\circ} 27^{\prime}$ $28^{\prime \prime}$ E), Inn Valley, Tyrol, $680 \mathrm{~m}$ alt, and subm by Gernot Patzelt, Geog Inst, Univ Innsbruck. Comments (GP): max age for beginning of Inn Valley gravel filling prior to last glaciation. (HF): No humic acid separation.

VRI-582. Lanersbach, Tirol

$7830 \pm 130$

Wood in landslide, Nandis-Alpe, E work Tux near Lanersbach $\left(47^{\circ}\right.$ $09^{\prime} 50^{\prime \prime} \mathrm{N}, 11^{\circ} 53^{\prime} 30^{\prime \prime} \mathrm{E}$ ), Tyrol. Coll 1975 and subm by Ilse Draxler, Geol BA, Vienna. Comment (ID): dates landslide.

\section{B. GSSR, Italy, Nepal, Saudi Arabia}

\section{Boubínský prales series, CSSR}

Carr peat of reservation Boubínský prales, Bohemian Woods $\left(48^{\circ}\right.$ $\left.56^{\prime} 30^{\prime \prime} \mathrm{N}, 13^{\circ} 50^{\prime} 50^{\prime \prime} \mathrm{E}\right), 960 \mathrm{~m}$ alt, CSSR. Coll 1975 and subm by $\mathrm{A}$ Kriesl and F Kral, Univ Bodenkultur, Vienna.

General Comments (FK): chronologic classification of palynologically detected events was expected, but dates are too young. Possibly sample contamination by humic acids. (HF): No humic acid separation was possible.

VRI-546. 62-70cm

$4240 \pm 70$

Peat and wood remnants at depth 62 to $70 \mathrm{~cm}$. Comment (FK): date of beginning of fir and beech spread was expected, however too young by ca $1500 \mathrm{yr}$.

\section{VRI-547. 92-100cm}

Peat with silt at depth 92 to $100 \mathrm{~cm}$. Comment (FK): date of beginning of spruce spread was expected, however too young by ca $2500 \mathrm{yr}$.

\section{VRI-499. Forcellona, Italy}

$8900 \pm 130$

Carex-carr peat at depth 110 to $120 \mathrm{~cm}$ from lowland moor near Forcella $\left(46^{\circ} 57^{\prime} 40^{\prime \prime} \mathrm{N}, 11^{\circ} 37^{\prime} \mathrm{E}\right), 1330 \mathrm{~m}$ alt, Italy. Coll 1974 and subm by Friedrich Kral. Comment (FK): date of palynologic interest, proving assumption of relatively rapid spread of spruce from refuge at SE border of E Alps against W.

\section{Sarnthein series, Italy}

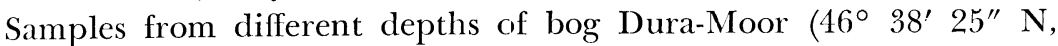
$11^{\circ} 27^{\prime} 35^{\prime \prime}$ E), Villanders-Berg near Sarnthein, Italy. Bog is outside of outermost end moraines of Egesen phase. Coll 1976 by boring and subm by Sigmar Bortenschlager.

General Comment (SB): dates palynologically detected events. Dates fit expectation. 
VRI-539. 450-472.5cm

$10,020 \pm 190$

Gyttja in contact with clay from depth 450 to $472.5 \mathrm{~cm}$. Comment (SB): dates beginning of organic sedimentation and min age for ice retreat.

VRI-548. 385-405cm

$8920 \pm 130$

Gyttja from depth 385 to $405 \mathrm{~cm}$. Comment (SB): dates increase of Alnus, decrease of Pinus and beginning increase of Picea.

VRI-549. 330-340cm

$7870 \pm 140$

Gyttja from depth 330 to $340 \mathrm{~cm}$. Comment (SB): dates intersection of Picea with Pinus curve and beginning of Abies and Fagus curve.

VRI-553. Sarnthein, Italy

$9370 \pm 150$

Gyttja from base of bog Schwarzsee, depth 375 to $383 \mathrm{~cm}$, VillandersBerg (46 $39^{\prime} 59^{\prime \prime} \mathrm{N}, 11^{\circ} 25^{\prime} 55^{\prime \prime}$ E) near Sarnthein, Italy. Coll 1976 and subm by Sigmar Bortenschlager. Comment (SB): date is min for ice retreat in area and beginning of vegetation.

\section{Kathmandu series, Nepal}

Samples in lake sediments of Kathmandu Valley, Nepal. Coll 1977 by Herbert Franz, subm by H Müller, Univ Bodenkultur, Vienna.

General Comment $(\mathrm{HF})$ : clue to age of terraces in Kathmandu Valley (Franz \& Kral, 1975) in relation to tectonic movements.

VRI-607. Chobar-Hill

Pine cones and bark near cement factory $S$ Kathmandu $\left(27^{\circ} 40^{\prime} \mathrm{N}\right.$, $85^{\circ} 15^{\prime}$ E) found in drain ditch at base of Chobar Hill. Site several meters below upper edge of lake sediments.

VRI-608. Karpathi

$29,200 \pm 1100$

Wood in lake sediments below brown colluvium; near Karpathi, N border of Kathmandu Valley $\left(27^{\circ} 42^{\prime} \mathrm{N}, 85^{\circ} 27^{\prime} \mathrm{E}\right)$.

VRI-599. Farasan, Saudi Arabia

$4330 \pm 100$

Shells in coastal terrace of island of Farasan $\left(16^{\circ} 35^{\prime} \mathrm{N}, 42^{\circ} 10^{\prime} \mathrm{E}\right)$, Saudi Arabia. Coll 1977 and subm by Josef Zötl, Hydrogeol, TU Graz. Comment (JZ): coastal terrace may be caused by tectonic uplift or by sea-level fluctuation of Red Sea. Date can be compared to age of known phases of raised sea level.

VRI-600. Harat Al Birk, Saudi Arabia

Shell in ancient shoreline along $\mathrm{S}$ margin of Harat Al Birk $\left(18^{\circ} 08^{\prime}\right.$ N, $41^{\circ} 36^{\prime}$ E), Saudi Arabia. Coll 1977 and subm by Josef Zötl. Comment (JZ): dates shoreline. 
VRI-601. Wadi Al Atk, Saudi Arabia

( $1.8 \pm 0.4) \%$ modern

Crusts of calcareous sinter in base of young terrace sediments in Wadi Alt Atk (Lithimah, $20^{\circ} 15^{\prime}$ N, 41 ${ }^{\circ} 38^{\prime}$ E), Saudi Arabia. Coll 1977 and subm by Josef Zötl. Comment (JZ): dates overlying gravel terrace. An assumed recent activity of $85 \%$ modern (Münnich \& Vogel, 1959; Geyh \& Schillat, 1966) gives model age $30,900+2000$; upper age limit $32,200+2000$ is obtained with $100 \%$ modern.

II. ARCHAEOLOGIC AND HISTORIC SAMPLES

$$
\text { A. Austria }
$$

\section{VRI-577. Falkenstein, Nö}

Charcoal in hearth pit at depth $120 \mathrm{~cm}$ in hut cut in Quads 6 to 9, excavation at Schanzboden (ring rampart) near Falkenstein ( $48^{\circ} 43^{\prime} 22^{\prime \prime}$ N, $16^{\circ} 35^{\prime} 05^{\prime \prime} \mathrm{E}$ ), Lower Austria. Coll 1976 and subm by Johann-Wolfgang Neugebauer, Bundesdenkmalamt, Vienna. Comment (J-W N): ca $600 \mathrm{yr}$ too young.

VRI-596. Weyregg, Oö

Wood from piling at depth $-2 \mathrm{~m}$ in lake Attersee, Weyregg $\left(47^{\circ} 54^{\prime}\right.$ N, $13^{\circ} 34^{\prime} 17^{\prime \prime} \mathrm{E}$ ), Upper Austria. Coll 1977 and subm by Johann Offenberger, Bundesdenkmalamt, Vienna. Comment (JO): remnant of wharf or breakwater of unknown age.

\section{VRI-578. Unterbuchberg, Oö}

$$
1450 \pm 70
$$

Wood remnant at base of Lake Attersee, depth $-1.5 \mathrm{~m}$, Unterbuchberg $\left(47^{\circ} 52^{\prime} \mathrm{N}, 13^{\circ} 33^{\prime} \mathrm{E}\right.$ ), Upper Austria. Coll 1976 and subm by Johann Offenberger. Comment (JO): date disproves expected La Tène age. De Vries corrected age is AD 570 (Suess, 1970).

VRI-579. Fuschl, Salzburg

$$
1430 \pm 90
$$

Wooden piling at base of Lake Fuschlsee, depth $-1 \mathrm{~m}$, near Schlo $\beta$ Fuschl $\left(47^{\circ} 48^{\prime} 30^{\prime \prime} \mathrm{N}, 30^{\circ} 55^{\prime} \mathrm{E}\right)$, Salzburg. Coll 1972 and subm by Bundesdenkmalamt, Vienna. Comment (BDA): dates disproves assumption of Neolithic lake-dwelling relict.

VRI-583. Pfarrwerfen, Salzburg

Wooden plank of track road below $2.5 \mathrm{~m}$ loamy soil; Pfarrwerfen $\left(47^{\circ} 21^{\prime} \mathrm{N}, 13^{\circ} 12^{\prime} \mathrm{E}\right)$, Salzburg. Coll 1976 and subm by Friederich Moosleitner, Mus Carolino Augusteum, Salzburg. Comment (FM): parts of track road on stone are found at many locations between Salzburg and Villach. This 1st wooden sample should decide between Roman and Middle age origin. Neither has been proven correct.

VRI-603. Waidmoos, Salzburg

$7000 \pm 130$

Wood below peat layer, $1.5 \mathrm{~m}$ thick, near Waidmoos bei Lamprechtshausen $\left(48^{\circ} 01^{\prime} \mathrm{N}, 12^{\circ} 57^{\prime} \mathrm{E}\right)$, Salzburg. Coll 1977 and subm by E Stüber, Haus d Natur, Salzburg. Comment (ES): dates bones of domestic pig found in same layer. 
VRI-598. Vienna

$$
2330 \pm 80
$$

Charcoal from settlement of Hallstatt culture excavated in Vienna 10, Unterlaa $\left(48^{\circ} 08^{\prime} \mathrm{N}, 16^{\circ} 25^{\prime} \mathrm{E}\right)$. Coll 1976 and subm by Ordolf Harl, Mus Stadt Wien. Comment $(\mathrm{OH})$ : precisely dates settlement.

\section{Kordlar series, Iran}

$$
\text { B. Iran, Iraq }
$$

Charcoal excavated from settlement hill, $28 \mathrm{~m}$ elev, Tepe Kordlar $\left(37^{\circ} 50^{\prime} \mathrm{N}, 45^{\circ} \mathrm{E}\right)$, near Rezaiyeh, W Aserbeidschan, Iran. Coll 1976 and subm by Andreas Lippert, Inst Vor- u Frühgesch, Univ Innsbruck.

General Comment (AL): samples complete dates of Early Iron age layers (R, 1979, v 21, p 119).

VRI-479. Sample 1/1976

Room B near S entrance, oldest Iron age horizon.

VRI-480. Sample 2/1976

$2640 \pm 80$

Room Z, Layer IV.

VRI-632. Tell Ababra, Iraq

Charcoal in Layer 1, Pit E, Tell Ababra, Sec B, Gabal Hamrin-Areal (ca $34^{\circ} 14^{\prime} \mathrm{N}$, ca $45^{\circ} 03^{\prime} \mathrm{E}$ ) Iraq. Site not found on maps. Coll 1978 by M Ludescher, subm by Inst $\mathrm{f}$ Sprachen u Kulturen des Alten Orients, Univ Innsbruck. Comment (ML): dates archaeol layer.

\section{REFERENCES}

Franz, H and Kral, F, 1975, Pollenanalyse und Radiokarbondatierung einiger Proben aus dem Kathmandubecken und aus dem Raum von Jumla in Westnepal: Sitzungsber Österr Akad Wiss, Wien, v 184, p 7-17.

Fritz, A, 1971, Das Interglazial von Nieselach: Carinthia II, p 317-330, Klagenfurt.

Geyh, M and Schillat, B, 1966, Messungen der Kohlenstoffisotpenhäufigkeit von Kalksinterproben aus der Langenfelder Höhle: Aufschlu $\beta$, v 17, p 315-323.

Mayr, F, 1964, Untersuchungen über Ausma $\beta$ und Folgen der Gletscher- u Klimaschwankungen seit Beginn der postglazialen Wärmezeit: Zeitschr Gcomorph NF, v 8, p 257-285.

1968, Postglacial glacier fluctuations and correlations phenomena in the Stubai Mountains, Eastern Alps, Tyrol: INQUA 1965, Univ Colorado Studies, Ser in Earth Sci, v 7, p 167-177.

Münnich, K O and Vogel, J, 1959, C-14 Altersbestimmungen von Sü $\beta$ wasser-Kalkablagerungen: Naturwiss, v 46, p 168-169.

Suess, H E, 1970, in Olsson, I U, (ed) Radiocarbon variations and absolute chronology: Stockholm, Almqvist and Wiksell. 